\title{
Couples Considering a Blended Family 1
}

Kate Fogarty, Millie Ferrer, and Sara McCrea ${ }^{2}$

\section{A Life-Changing Step!}

Congratulations, you have decided to embark on a life change and challenge-blending families!

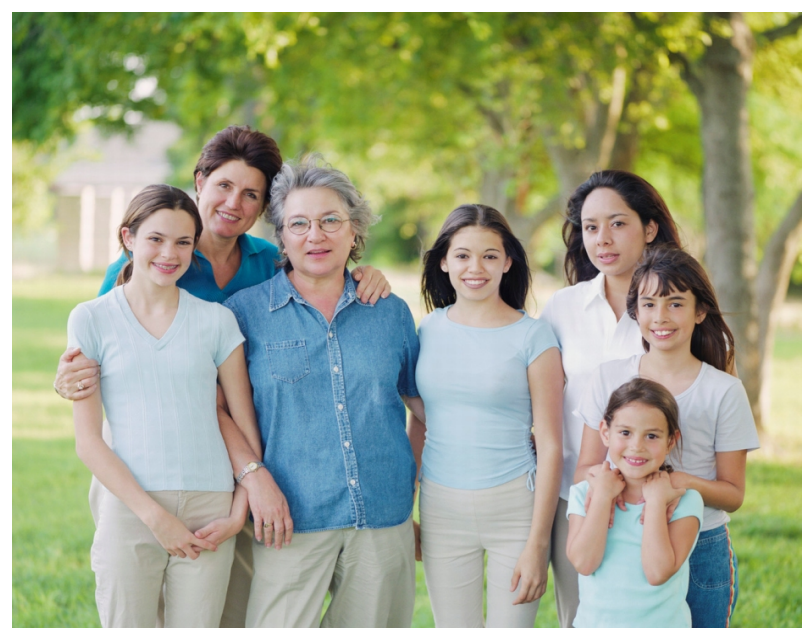

You have likely learned through experience that building a good relationship does not happen instantly. It takes time, effort, commitment, and lots of patience. As a new couple with children from a previous relationship, you face special challenges. You need to work on building a solid and committed relationship with each other, while including each other's children in the family.
Avoid having the same expectations for your blended family that you would for a nuclear (or your previous) family arrangement. Having realistic expectations makes the difference. Making sure all stepfamily members know one another well is crucial before you remarry.

Family therapists find that forming a healthy stepfamily is a challenging task. This process can take anywhere from four to seven years of adjustment. Trying to merge two families too quickly may lead to disappointment as some family members may resist bonding.

Work on the couple relationship as the first step to forming a healthy blended family. It is important to spend quality "alone" time together and nurture one another through positive communication. This is especially important because the relationships you and/or your spouse have with your biological children started way before (and may be stronger than) your couple relationship.

Every relationship requires work and no two relationships are alike. Part of that work involves dealing with loss, pain, and bitterness from a previous relationship so that it does not undermine your current

1. This document is FCS2148, one of a series of the Family Youth and Community Sciences Department, Florida Cooperative Extension Service, Institute of Food and Agricultural Sciences, University of Florida. Original publication date November 1, 2001. Revised June 16, 2006. Visit the EDIS Web Site at http://edis.ifas.ufl.edu.

2. Revised by Kate Fogarty, Ph.D., assistant professor, youth development, written by Evelyn Rooks-Weir, former associate professor, Human Development, revised by Millie Ferrer, Ph.D., associate professor, Human Development, Department of Family, Youth and Community Sciences, Cooperative Extension Service, Institute of Food and Agricultural Sciences, University of Florida, Gainesville, 32611.

The Institute of Food and Agricultural Sciences (IFAS) is an Equal Opportunity Institution authorized to provide research, educational information and other services only to individuals and institutions that function with non-discrimination with respect to race, creed, color, religion, age, disability, sex, sexual orientation, marital status, national origin, political opinions or affiliations. U.S. Department of Agriculture, Cooperative Extension Service, University of Florida, IFAS, Florida A. \& M. University Cooperative Extension Program, and Boards of County Commissioners Cooperating. Larry Arrington, Dean 
relationship. In fact, rejection, loss, and guilt from past relationships can emerge in ways that neither partner expects or understands. It is unhealthy for couples to ignore differences and past issues that need to be resolved. Be honest with yourself and your spouse as you read over the material presented here. Answer the questions in the chart on the next to last page. Through open communication and sincerity you will be on your way to strengthening your new family lifestyle.

\section{Family Ties}

As you both work to form a strong, blended family, you need to be aware of certain things:

- Blended family relationships are going to be different from those in a family with two biological parents. Healthy stepfamilies tend to have less loyalty among members and have more flexible family boundaries than healthy nuclear families.

- Stepchildren usually do not expect a stepparent to act like or replace a biological parent. What is most important is a mutually satisfying relationship between stepparent and stepchild. In some cases, it is acceptable for stepparents to act as a biological parent and in other cases, it is better for stepparents to act more like a friend or mentor.

- Keep in mind that it may be hard for children to express their feelings appropriately. Children are not born knowing how to understand and express their feelings and need to learn and practice these skills over time.

- Children may also have a hard time adjusting to the other changes a new marriage brings: new stepsiblings, a new house, or a new school.

- Teenagers may have additional difficulties. Teens tend to experience the transition to remarriage and stepfamily formation negatively. Teens often resent the lack of decision-making power in the changes of living space, relationships and expectations as well as feeling excluded from their relationship with their biological parent. Be aware that teens who move from a single parent family into stepfamilies are at a higher risk for problem behaviors such as alcohol use (refer to EDIS publication FCS9231/FY767 Alcohol and Drug Use During Adolescence: Problems and Solutions Youth Professionals Need to Know).

\section{New Roles Come with Your New Life}

Make changes as slowly as possible and keep arrangements as consistent as possible.

Consistency helps children feel a sense of stability. The best way to develop positive relationships within your new family are to take time to talk and listen to each other. All members, especially teens becoming adults, need to feel their opinions are valued and considered during decision-making. To reduce the amount of discontent in the family, each member should be encouraged to express his or her feelings. Emotions and situations in stepfamilies tend to be more intense and complicated. Adults need to allow children, regardless of their age, to process and express their feelings--even when their feelings and concerns are difficult for you to hear.

\section{Role of the Stepparent}

The role of a stepparent is not necessarily to be the household disciplinarian. As a stepparent, it may be better to avoid making decisions regarding your stepchild's behavior. This does depend on the circumstances involved. Instead of trying to parent your stepchild, it may be better to try to be a mentor or supporter to the child.

If you do not agree with how your spouse handles a particular situation, discuss these issues privately, not in front of the child. Showing support for your spouse is vital in developing a positive marital relationship. Talk with your partner about your concerns-- without being judgmental.

Should you have concerns about a child's behavior, be sensitive to the fact that the child is trying to adjust to a new lifestyle. Keep a positive attitude; focus on the child's positive qualities. As time passes, your role as a stepparent may change. You may choose to be more involved with the child. 
Remember, though, you cannot force a close relationship. Take cues from the child about how involved they want you to be. Parenting your own children can often feel exhausting; being a stepparent is sometimes even more challenging. It can be frustrating and discouraging if the relationship with your stepchild is not what you would like it to be. With patience, consistency, forbearance, and time things will improve!

\section{Role of the Biological Parent}

As a biological parent in the new household, you have a close relationship to all family members. You play a critical role in the development of a positive relationship between your child and your new spouse or partner.

As the biological parent, you are primarily responsible for disciplining your child, although you may choose to share this responsibility with your spouse. Children may become angry and resentful that someone who is not their parent is making rules for them, which could be the case if your new spouse becomes the disciplinarian too soon.

Also, make sure your child understands the need to treat your new spouse or partner kindly and with respect. Often children feel uneasy, nervous, or fearful toward a new stepparent. While it is fine for children to have these feelings, you need to make it clear that rude or mean behavior toward the new stepparent will not be tolerated.

As you both work to establish your new household, make sure that your spouse has an understanding of the family's past discipline, household rules, and responsibilities. This understanding will help your spouse or partner be supportive as you try to make rules and responsibilities that are consistent for your biological child. (Make sure your partner gives you the same information regarding your stepchild/ren.)

Also, as the biological parent, recognize that you have a bond with your child that your new spouse or partner does not share. This can leave him or her feeling isolated. Be sensitive to this and try to include your spouse or partner in daily routines as much as possible. Be sure to find activities that you all enjoy doing together. Do not forget the importance of getting one-on-one time with your child/ren. If children are not getting enough alone time with you they may feel jealous of the new stepparent. It is not easy to balance all the needs in a blended family, but you can do it!

\section{Where Do You Go from Here?}

The following questions will help you to assess your family views. The questions will help you and your future spouse to think about how you will model positive relationships with your new family.

Table 1.

\begin{tabular}{|c|c|}
\hline \multicolumn{2}{|r|}{$\begin{array}{l}\text { Questions for Potential Stepparents } \\
\text { Consider the following regarding your role as a } \\
\text { stepparent. There are no right or wrong answers, } \\
\text { only what you honestly feel. Share your } \\
\text { responses with your future spouse when you are } \\
\text { both done. You may decide to make a contract for } \\
\text { your blended family based on your answers to } B \text {, } \\
\text { and } D-G \text {. }\end{array}$} \\
\hline$A$ & $\begin{array}{l}\text { Describe at least two characteristics you } \\
\text { value in each child in the family. }\end{array}$ \\
\hline$B$ & $\begin{array}{l}\text { Do you want to have more children together? } \\
\text { If so, describe the changes this would bring to } \\
\text { your current lifestyle and your family situation. } \\
\text { How will you allocate child raising } \\
\text { responsibilities and tasks (for example, } \\
\text { discipline)? }\end{array}$ \\
\hline $\mathrm{C}$ & $\begin{array}{l}\text { What are your biggest concerns about being a } \\
\text { stepparent? }\end{array}$ \\
\hline $\mathrm{D}$ & $\begin{array}{l}\text { What will you do to establish a strong } \\
\text { relationship with your children? }\end{array}$ \\
\hline $\mathrm{E}$ & $\begin{array}{l}\text { How will family responsibilities be shared? } \\
\text { What do you expect children to be } \\
\text { responsible for? }\end{array}$ \\
\hline$F$ & $\begin{array}{l}\text { How will you make time for each other as a } \\
\text { couple with your new family arrangement? } \\
\text { How will you make one-on-one time with your } \\
\text { biological child(ren)? What kinds of vacations } \\
\text { will you take (as a couple only/as a family?) }\end{array}$ \\
\hline $\mathrm{G}$ & $\begin{array}{l}\text { How will you relate to one anothers relatives, } \\
\text { ex-spouses or previous partners, and their } \\
\text { families? }\end{array}$ \\
\hline
\end{tabular}




\section{Tips for Blended Families}

The following can help make the transition into a new relationship or remarriage with children easier. Read them and check off at least three from each list that applies to you. Then commit yourself to using them in your new household

\section{For Biological Parents:}

- Create structure in the household.

- Establish clear rules and consequences.

- Allow children to give input about the rules.

- Model the behaviors you want your children to practice.

- Allow children to express their feelings openly.

- Take time to be alone together as a couple.

- Try to find activities that you all can do together.

\section{For Stepparents:}

- Look for the positive things about each child.

- Support the discipline practices of the biological parent.

- Avoid assuming the role of a strict disciplinarian - rather, act as a guide or friend depending on the given situation.

- Be prepared for children to express conflicting loyalties.

- Listen to children with your full attention.

- Don't use unkind words; instead use positive communication and affirmation.

- Don't expect too much at once; do not expect instant love.

- Don't get discouraged. Patience is the key!

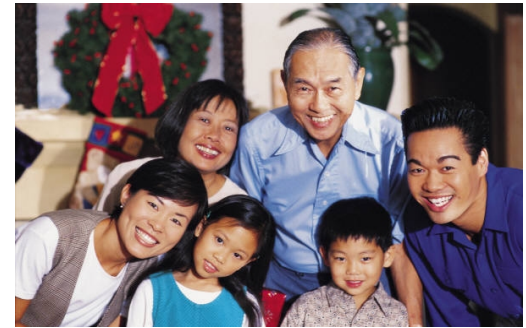

Resources for Stepfamilies

Focus Adolescent Services - Helping your teen adjust to stepfamily formation

http://www.focusas.com/Adjust.html

Stepfamily Association of America (A nonprofit organization providing membership, information, and services to blended families).

http://www.saafamilies.org/index.htm

\section{Reference List}

Bray, J.H. (1999). From marriage to remarriage and beyond. pp. 253-271 in Coping with divorce, single parenting and remarriage. Edited by E.M. Hetherington. Mahwah, NJ: Erlbaum.

Ferrer, Millie. 1998. "Tots in Action: 12-18 Months." FCS2124. 4pp.

Ferrer, Millie. 1998. "Tots in Action: 24-36 Months." Florida Cooperative Extension Service, IFAS, University of Florida, Gainesville. FCS2129. $4 \mathrm{pp}$

Ferrer, Millie and Sara McCrea. 2000." Let's Talk about Temper Tantrums." Florida Cooperative Extension Service, IFAS, University of Florida, Gainesville. FCS2153. 4pp.

Fine, M.A., Coleman, M. \& Ganong. L.H. (1998). Consistency in perceptions of the step-parent role among step-parents, parents, and stepchildren. Journal of Social \& Personal Relationships, 15, 810-828.

Fine, M.A., Ganong, L.H., \& Coleman, M. (1997). The relation between role constructions and adjustment among stepfathers. Journal of Family Issues, 18, 503-525. 
Gamache, S.J. (1997). Confronting nuclear family bias in stepfamily research. Marriage \& Family Review, 26, 41-50.

Hamner, Tommie, and Pauline Turner. 1996. Parenting in Contemporary Society. Allyn \& Bacon. Boston. 400pp.

Ihinger-Tallman, M., \& Pasley, K. (1997). Remarriage. Newbury Park, CA: Sage.

Kheshgi-Genovese, Z., \& Genovese, T.A. (1997). Developing the spousal relationship within stepfamilies. Families in Society, 78, 255-264.

Kirby, J.B. (2006). From single-parent families to stepfamilies: Is the transition associated with adolescent alcohol initiation? Journal of Family Issues, 27, 685-711.

Manczak, D.W. (1999). Remarriage. Clinical Reference Systems, Nov. 1.

Nelsen, Jane. 1981. Positive Discipline. Ballantine Books. NY, NY. 258pp.

Papernow, P. (1993). Becoming a stepfamily: Patterns of development in remarried families. San Francisco: Jossey-Bass.

Stepfamily Association of placecountry-regionAmerica (n.d.). Frequently Asked Stepfamily Questions (FAQs) http://www.saafamilies.org/faqs/faqs.htm

Stoll, B.M., Arnaut, G.L., Fromme, D.K., \& Felker-Thayer, J.A. (2005). Adolescents in stepfamilies: A qualitative analysis. Journal of Divorce \& Remarriage, 44, 177-189.

Wark, L., \& Jobalia, S. (1998). "What would it take to build a bridge? An intervention for stepfamilies."Journal of Family Psychotherapy, 9, 69-77.

Bray, J.H. (1999). From marriage to remarriage and beyond. pp. 253-271 in Coping with divorce, single parenting and remarriage. Edited by E.M. Hetherington. Mahwah, NJ: Erlbaum.
Ferrer, Millie. 1998. "Tots in Action: 12-18 Months." Fla. Coop. Exten. Serv., IFAS, Univ. Fla, Gainesville. FCS 2124. 44 pp.

Ferrer, Millie. 1998. "Tots in Action: 24-36 Months."Fla. Coop. Exten. Serv., IFAS, Univ. Fla, Gainesville. FCS 2129. 4 pp.

Ferrer, Millie and Sara McCrea. 2000." Let's Talk about Temper Tantrums." Univ. Fla, Coop. Exten. Serv. FCS 2153. 4 pp.

Fine, M.A., Coleman, M. \& Ganong. L.H. (1998). Consistency in perceptions of the step-parent role among step-parents, parents, and stepchildren. Journal of Social \& Personal Relationships, 15, 810-828.

Fine, M.A., Ganong, L.H., \& Coleman, M. (1997). The relation between role constructions and adjustment among stepfathers. Journal of Family Issues, 18, 503-525.

Gamache, S.J. (1997). Confronting nuclear family bias in stepfamily research. Marriage \& Family Review, 26, 41-50.

Hamner, Tommie, and Pauline Turner. 1996. Parenting in Contemporary Society. Allyn \& Bacon. Boston. 400pp.

Ihinger-Tallman, M., \& Pasley, K. (1997). Remarriage. Newbury Park, CA: Sage.

Kheshgi-Genovese, Z., \& Genovese, T.A. (1997). Developing the spousal relationship within stepfamilies. Families in Society, 78, 255-264.

Kirby, J.B. (2006). From single-parent families to stepfamilies: Is the transition associated with adolescent alcohol initiation? Journal of Family Issues, 27, 685-711.

Manczak, D.W. (1999). Remarriage. Clinical Reference Systems, Nov. 1.

Nelsen, Jane. 1981. Positive Discipline. New York: Ballantine Books.

Papernow, P. (1993). Becoming a stepfamily: Patterns of development in remarried families. San Francisco: Jossey-Bass. 
Stepfamily Association of America (n.d.). Frequently Asked Stepfamily Questions (FAQs) HYPERLINK

"http://www.saafamilies.org/faqs/faqs.htm" http://www.saafamilies.org/faqs/faqs.htm

Stoll, B.M., Arnaut, G.L., Fromme, D.K., \& Felker-Thayer, J.A. (2005). Adolescents in stepfamilies: A qualitative analysis. Journal of Divorce \& Remarriage, 44, 177-189.

Wark, L., \& Jobalia, S. (1998). "What would it take to build a bridge? An intervention for stepfamilies."Journal of Family Psychotherapy, 9, 69-77. 